\title{
Fermentative Production of nata-de-cashew from Calcium Alginate Incorporated Cashew Apple Juice Medium
}

\author{
Gayathry, G. ${ }^{{ }^{*}}$ and Jothilakshmi, K. ${ }^{2}$ \\ ${ }^{1}$ Assistant Professor (Agricultural Microbiology), Sugarcane Research Station, TNAU, Cuddalore, Tamil Nadu, India \\ ${ }^{2}$ Assistant Professor, Community Science College and Research Institute, Madurai, TNAU, Tamil Nadu, India
}

*Corresponding author: gayathryg@tnau.ac.in

\begin{abstract}
Nata produced by Gluconacetobacter xylinum is a pure form of cellulose without lignin and hemicelluloses unlike plant cellulose. The production of bacterial cellulose or nata is receiving great attention due to its wide range of application both in food and pharmaceutical industries. However, the yield is comparatively very low and the commercially used carbon sources such as glucose are relatively expensive. In this study, a pilot scale bacterial cellulose production was carried out in a 5 L capacity model jar fermentor using G. oboediens (sju-1) Acc. No. KF164613 in calcium alginate incorporated cashew apple juice (CAJ) medium. Fermentation kinetics of bacterial cellulose production was evaluated during the course of reaction. The population increase with a gradual decrease in $\mathrm{pH}$ was noticed up to $16^{\text {th }}$ day of inoculation. Initially the

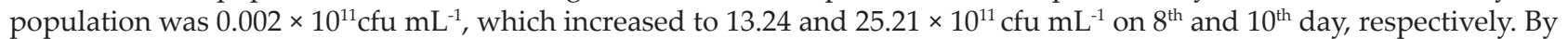
$16^{\text {th }}$ day of incubation, the population reached the maximum of $34.12 \times 10^{11} \mathrm{cfu} \mathrm{ml}^{-1}$ and the $\mathrm{pH}$ of the medium dropped to 4.5. Bacterial cellulose produced per $100 \mathrm{~g}$ of the substrate ( $\mathrm{Yp} / \mathrm{s})$ was $1.62 \pm 0.01 \mathrm{~g}$, while it was found to be $1.30 \pm 1.11 \mathrm{~g}$. $100 \mathrm{~g}^{-1}$ of cells $(\mathrm{Yp} / \mathrm{x})$. With respect to total sugars, the initial concentration of $18.00 \mathrm{~g} . \mathrm{L}^{-1}$ dropped to $16.14,10.88$ and 9.14 g. $\mathrm{L}^{-1}$ on $2^{\text {nd }}, 6^{\text {th }}$ and $8^{\text {th }}$ day, respectively. On the $16^{\text {th }}$ day when the population of bacterial cells was at the maximum, the total sugar content dropped drastically to $2.18 \mathrm{~g} \mathrm{~L}^{-1}$. Due to the incorporation of calcium alginate in medium, the yield of nata-de-cashew increased and the mass production was found to be easier compared to the flask culture. Hence, it is concluded that, addition of calcium alginate to CAJ medium under static condition, inoculated with G. oboediens (sju-1) NCBI GenBank Acc. No. KF164613 in a modified jar fermentor could increase the production of nata.
\end{abstract}

Keywords: Gluconacetobacter oboediens, Cashew apple juice medium, Calcium alginate, nata-de-cashew, Static jar fermentor

Gluconacetobacter xylinum is usually cultured under static fermentation in a chemically undefined medium called HS medium (Hestrin and Schramm, 1954). Addition of supplements to the cell culture medium like endoglucanase, pyruvate, ethanol, lactate and sodium alginate would boost the nata or bacterial cellulose production (Hungund et al. 2013). Anusuya et al. (2020) had reported that Acetobacter senegalensis MA1 produces bacterial cellulose of about $3.6 \mathrm{~g}$ in Hestrin and Schramn medium.
The bacterial cellulose production by $A$. xylinum NUST 4.1 carried out by adding sodium alginate (NaAlg) into the medium significantly enhanced the yield and modified the crystalline properties of cellulose. Various water soluble polymers added into the medium were known to interfere with the

How to cite this article: Gayathry, G. and Jothilakshmi, K. (2020). Fermentative Production of nata-de-cashew from Calcium Alginate Incorporated Cashew Apple Juice Medium. Intl. J. Ferment. Food, 9(2) $37-41$.

Source of Support: None; Conflict of Interest: None 
aggregation of microfibrils into a normal ribbon assembly. Addition of water-soluble polymers such as xanthan, agar, polyacrylamide-co-acylic acid (PCA) and acetan can increase relative viscosity of the broth to reduce shear stress, hinder coagulation of bacterial cellulose during the cultivation to form uniform smaller pellets, which were found to be advantageous to transfer nutrients and oxygen into bacterial cells located inside and on the surface of the cellulose matrix (Zhou et al. 2007). The yield of nata not only depends on the composition of culture medium, but also relies upon the concentration, surface, volume, $\mathrm{pH}$, aeration of the medium, cultivation method, reactor type and temperature (Chawla et al. 2009). The most common bacterial cellulose synthesis method is static culture, which could produce cellulose in the form of pellicles on air / liquid interface. Quite a number of studies demonstrated improvements in bacterial cellulose production under dynamic conditions, using different devices such as static tray fermentor, rotating disk, air-lift, agitated and shaking reactors (Hornung et al. 2007). Improved fermentation processes are required for a breakthrough towards an economical process for bacterial cellulose production. Lin et al. (2016) has reported that bacterial cellulose film, hydroxylpropyl-methyl cellulose modified bacterial cellulose and dried fabricated biofilm were found to be suitable candidates for applications in delayed and rapid drug release type biofilms in pharmaceutical applications. Hence, in the present research, a modified low cost jar fermentor was designed to improve the yield of nata-de-cashew for various applications.

Carvalho et al. (2007) have developed a blended beverage, based on coconut water, cashew apple juice and caffeine for bacterial cellulose production. Kurosumi et al. (2009) developed an effective culture method and investigated for the possibility of producing bacterial cellulose from orange, pineapple, apple, Japanese pear and grape fruit juices by Acetobacter xylinum NBRC 13693.

Costa et al. (2009) have developed fruit powders from cashew apple and guava (Psidium guajava L.) residues after extracting of the juice and used as a source of vitamin $\mathrm{C}$ and lipid, respectively. However, cashew apple-based products are not commercially popular in India, unlike in Brazil and other countries. Cashew apple contains tannins, causing astringency, which needs to be precipitated out before making juice. According to the report of Tigressa et al. (2008) only $12.0 \mathrm{~g}^{1} 100 \mathrm{~g}^{-1}$ of the total peduncle is processed. Honorato et al. (2007) have illustrated that cashew apple juice has been used for the production of surfactants, alcoholic beverages and syrup. However, mostly the pseudo fruit is underutilized and often fed to cattle and pigs. Being a rich source of sugar, cashew apple after extraction of nut could be a cost effective culture medium for the production of bacterial cellulose in static fermentor. Hence, this research work was carried out to explore the possibility of bacterial cellulose production from calcium alginate incorporated cashew apple juice medium by static fermentation, in a modified jar fermentor using an efficient cellulose producing bacterial strain isolated from sugarcane juice.

\section{MATERIAL AND METHODS}

\section{Starter culture and inoculum preparation}

The starter culture namely, Gluconacetobacter oboediens (sju-1) NCBI GenBank database accession number KF164613 used in this study, was previously isolated from fermenting sugarcane juice and identified at the Department of Agricultural Microbiology, Tamil Nadu Agricultural University, Coimbatore, India.

Gluconacetobacter oboediens (sju-1) Acc. No. KF164613 was cultured in Hestrin Schramn medium. Cashew apple juice with total soluble solids (TSS) of $25^{\circ}$ Brix was prepared and preserved at $4^{\circ} \mathrm{C}$. A modified cashew apple juice (CAJ) medium containing cashew apple juice, fructose, yeast extract, citric acid and disodium hydrogen phosphate were preoptimized to standardize the growth medium. Various components like agar, agarose, acetan, calcium alginate, chitin, chitosan, cellulose, carboxy methyl cellulose, dextran, gelatin, gellan, levan, lignosulfonate and poly ethylene glycol were taken at $0.1 \%$ level in separate $250 \mathrm{~mL}$ Erlenmeyer flasks and 
added with other components of pre-standardised medium, sterilized and inoculated with $24 \mathrm{~h}$ old culture of G. oboediens (sju-1) Acc. No. KF164613 containing $20 \times 10^{8} \mathrm{cfu} \mathrm{mL}^{-1}$ and incubated at $31^{\circ} \mathrm{C}$. Based on the yield of bacterial cellulose in the pre-optimized media (Cashew apple juice (1000 mL), $4.0 \mathrm{~g}$ fructose, $6.0 \mathrm{~g}$ yeast extract, $1.5 \mathrm{~g}$ citric acid, $0.5 \mathrm{~g}$ disodium hydrogen phosphate, $0.1 \%$, calcium alginate, $\mathrm{pH}$ 6.5) was taken for further study. Mother culture was also prepared using the standardized medium (Plate 1).

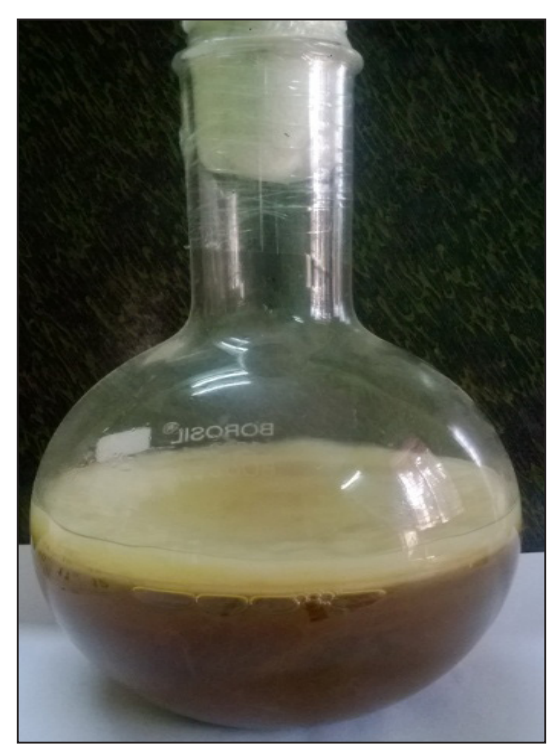

Plate 1: Mother culture of G. obediens in cashew apple juice medium

\section{Fermentation in a static jar fermentor}

A schematically designed (Fig. 1) 5.0 L capacity $\mathrm{TPX}^{\mathrm{TM}}$ poly-methyl-pentene transparent light weight autoclavable jar with handle was taken for laboratory scale production of nata-de-cashew under static fermentation during study. The lid was designed using GI sheet with four holes $(4 \mathrm{~cm})$ placed, at an equal distance and a handle at the centre. The holes were plugged with cotton for aeration. About 3.5 L of cashew apple juice medium was taken and closed with the lid. The entire set up was sterilized by autoclaving. After sterilization, $350 \mathrm{~mL}$ of seed culture was inoculated into it and incubated statically at $31^{\circ} \mathrm{C}$ for 20 days. Sample can be withdrawn through the holes with a sterile pipette for quantitative and qualitative analyses.

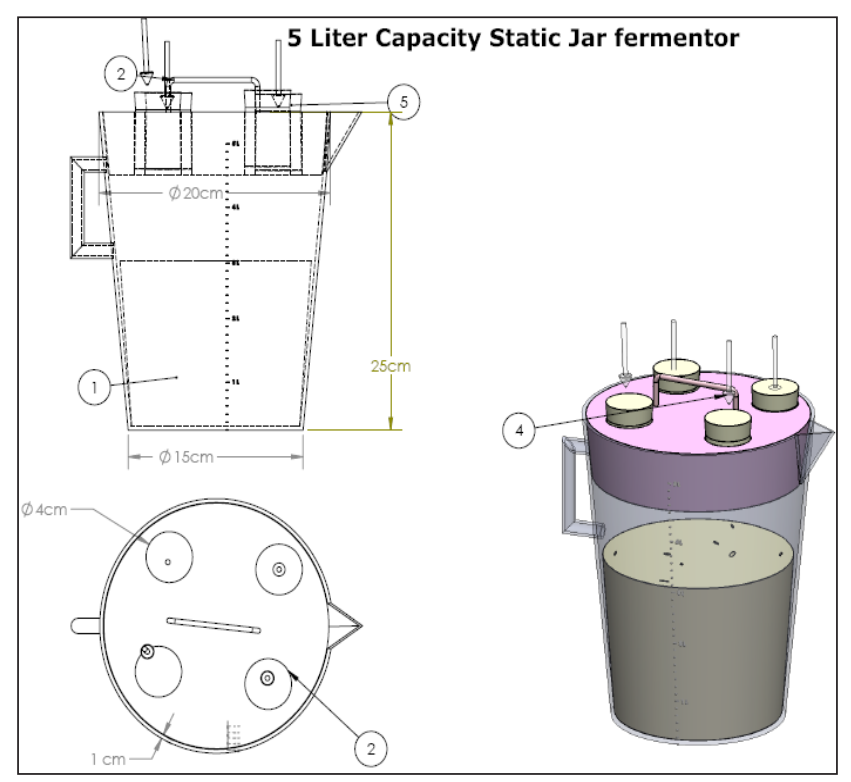

Fig. 1: Schematic design of laboratory scale static jar fermentor for the production of nata-de-cashew

\section{Fermentation kinetics in Cashew Apple Juice medium}

The growth kinetics of G. oboediens (sju-1) Acc. No. KF164613 in cashew apple juice medium under static fermentation in the pre-designed model fermentor was expressed in terms of growth rate $\left(\mathrm{k} \cdot \mathrm{g} \mathrm{L}^{-1} \mathrm{~d}^{-1}\right)$, specific growth rate $\left(\mu \cdot h^{-1}\right), C$ max $=$ maximum nata concentration $\left(\mathrm{g} . \mathrm{L}^{-1}\right), \mathrm{Qp}=$ Nata produced $\left(\mathrm{g} \cdot \mathrm{L}^{-1} \cdot \mathrm{h}^{-1}\right)$, $\mathrm{Yp} / \mathrm{s}=$ Nata produced $\left(\mathrm{g} .100 \mathrm{~g}^{-1}\right.$ of sugar source used in the medium and $\mathrm{Yp} / \mathrm{x}=$ Nata produced (g.100 g-1 of cells). Samples were withdrawn at two days interval up to 20 days of fermentation to quantify the changes in viable cell number, $\mathrm{pH}$ and total sugars following the methods suggested by (Keshk, 2014).

\section{RESULTS AND DISCUSSION}

The results of the fermentation kinetics of nata-de-cashew production under static fermentor using CAJ medium is presented in Table 1. The population increase from 0.002 to $34.12 \times 10^{11} \mathrm{cfu} \mathrm{mL}^{-1}$ with a gradual decrease in $\mathrm{pH}(4.5)$ was noticed up to $16^{\text {th }}$ day of inoculation. Thereafter the population reached its stationary phase $\left(31.22\right.$ and $33.14 \times 10^{11} \mathrm{cfu} \mathrm{mL} \mathrm{m}^{-1}$ on 
$18^{\text {th }}$ and $20^{\text {th }}$ day, respectively). On $20^{\text {th }}$ day the $\mathrm{pH}$ became very much acidic recording a value of 3.5. The initial concentration of total sugars was $18.00 \mathrm{~g}$ $\mathrm{L}^{-1}$ (Fig. 2), which dropped to $16.14,10.88$ and $9.14 \mathrm{~g}$ $\mathrm{L}^{-1}$ on $2^{\text {nd }}, 6^{\text {th }}$ and $8^{\text {th }}$ day, respectively. Interestingly, on the $16^{\text {th }}$ day when the bacterial population was at its maximum, the total sugar content dropped to $2.18 \mathrm{~g}$ $\mathrm{L}^{-1}$ which further decreased to1.50 $\mathrm{g} \mathrm{L}^{-1}$ at the end of the experiment (i.e., on $20^{\text {th }}$ day). It was also observed in the present study that, wide mouthed user friendly jar type model fermentor could give economical yield of nata-de-cashew using, G. oboediens strain sju-1 (NCBI Acc. No. KF164613).

Table 1: Fermentation kinetics of nata-de-cashew production using CAJ medium

\begin{tabular}{ll}
\hline Parameters & Observed values \\
\hline Growth rate $(\mathrm{K})\left(\mathrm{g} \cdot \mathrm{L}^{-1} \cdot \mathrm{d}^{-1}\right)$ & $0.0079 \pm 0.11$ \\
Specific growth rate $(\mu)\left(\mathrm{h}^{-1}\right)$ & $0.0031 \pm 0.04$ \\
Maximum Nata $(\mathrm{C}$ max $)\left(\mathrm{g} \cdot \mathrm{L}^{-1}\right)$ & $16.22 \pm 0.17$ \\
Nata production rate $(\mathrm{Qp})\left(\mathrm{g} . \mathrm{L}^{-1} \cdot \mathrm{h}^{-1}\right)$ & $0.27 \pm 0.10$ \\
Nata produced $(\mathrm{Yp} / \mathrm{s})\left(\mathrm{g} \cdot 100 \mathrm{~g}^{-1}\right.$ of & $1.62 \pm 0.01$ \\
substrate) & $1.30 \pm 1.11$ \\
Nata produced $(\mathrm{Yp} / \mathrm{x})\left(\mathrm{g} \cdot 100 \mathrm{~g}^{-1}\right.$ of cells $)$ & \\
\hline
\end{tabular}

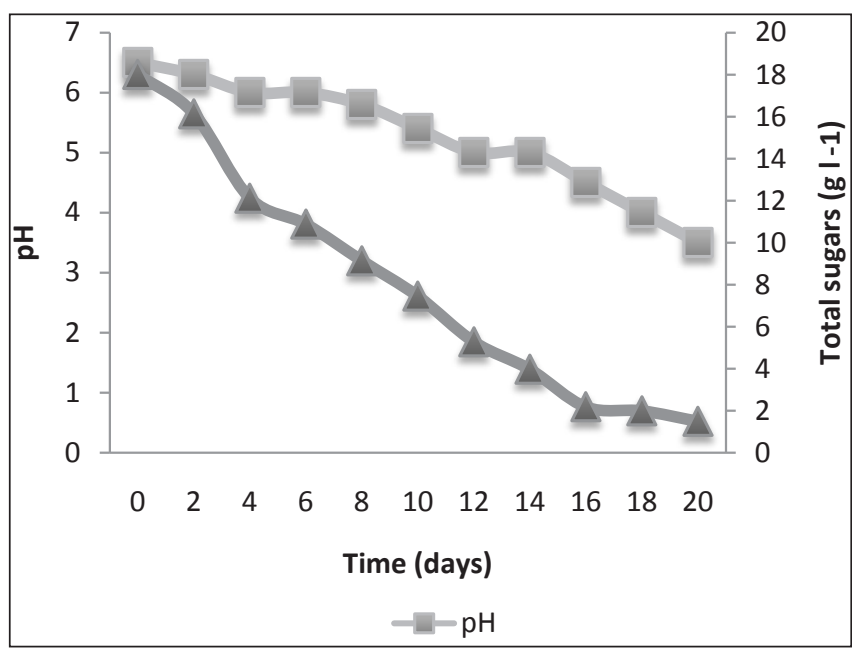

Fig. 2: Changes in $\mathrm{pH}$ and total sugars of $\mathrm{CAJ}$ medium during fermentation

Hornung et al. (2006) have explained the mass transfer reactions during the growth of $A$. xylinum. The cellulose growth rate ceased after about 15 days, but remnant glucose was found to be diffused through the layer and continued to be consumed, even after the stagnation of product formation, especially used for cell maintenance. After a brief lag phase, the number of cells, which produced nata-de-cashew increased exponentially reaching the maximum value of $8.3 \times 10^{9}$ cells and remained constant on the maximum value between days 8 to 10 during incubation. From $11^{\text {th }}$ day onwards the number of nata-de-cashew producing cells decreased due to the cessation of cellulose production. The results obtained from the present study paralleled with the above findings. Ishida et al. (2003) established the use of negatively charged water-soluble cellulose derivative, carboxymethylcellulose (CMC), agar and sodium alginate to enhance nata-de-cashew production in static culture. This study indicated that calcium alginate incorporation in to the production medium increased the yield of cellulose to $17.8 \pm 0.38$ $\mathrm{g} \mathrm{L}^{-1}$, whereas, previous studies involving cashew apple juice medium without incorporation of calcium alginate had given only $14.1 \pm 0.35 \mathrm{~g} \mathrm{~L}^{-1}$ of nata-de-cashew during static fermentation.

Jessica and Ari (2017) had reported that nata-de-coco produced without Ammonium sulphate is able to meet good the sensory values than the nata-de-coco produced with Ammonium sulphate. After 8 days of fermentation, 1.2 to $1.3 \mathrm{~cm}$ thickness of nata had formed with acidic $\mathrm{pH}$ of 4-5. In the present study similar type of thickness had been obtained with $\mathrm{pH}$ reduction to 4.5 during the course of fermentation.

Pal et al. (2019) had developed and standardized a ready to eat, dessert food, Nata-de-mango from mango pulp of $22^{\circ}$ Brix which had been incorporated into beverages upto $25 \%$ for high organoleptic acceptability. Similarly, the results of the present research uses cashew apple juice, with total soluble solids of $25^{\circ}$ Brix to produce nata-de-cashew would better serve as an adjuvants in the preparation of soft drinks.

Hence, an addition of polysaccharide like calcium alginate to the production medium prepared with 
underutilized sugar rich fruit juice like that of cashew apple is suggested for substantially increased natade-cashew production in bioreactors.

\section{ACKNOWLEDGEMENTS}

The authors are grateful to acknowledge the TNAU Research Assistantship from Tamil Nadu Agricultural University, Coimbatore, Tamil Nadu for the successful conduct of the research work.

\section{REFERENCES}

Anusuya, R.S., Anandham, R., Kumutha, K., Gayathry, G., Mageshwaran, V. and Uthandi, S. 2020. Characterization and optimization of bacterial cellulose produced by Acetobacter spp. J. Environ. Biol., 41(2): 207-215.

Carvalho, J.M., Maia, G. A., Figueiredo, R.W., Brito, E.S. and Rordrigues, S. 2007. Development of a blended beverage consisting of coconut water and cashew apple juice containing caffeine. Int. J. Food Sci. Technol., 42: 1195-1200.

Chawla, P., Bajaj, I.B., Survase, S. and R. Singhal. 2009. Fermentative production of microbial cellulose. Food Technol. Biotechnol., 47: 107-124.

Costa, J.M.C., Felipe, F.M.F., Maia, G.J. Hernandez, F.F.F. and Brasil, I.M. 2009. Production and characterization of the cashew apple (Anacardium occidentale L.) and guava (Psidium guajava) fruit powders. J. Food Process. Preserv., 33: 299-312.

Hestrin, S. and Schramn, M. 1954. Synthesis of cellulose by Acetobacter xylinum: preparation of freeze dried cells capable of polymerizing glucose to cellulose. Biochem. J., 58: $345-352$.

Honorato, T.L., Rabelo, M.N., Gonçalves, L.R.B., Pinto, G.A.S. and Rodrigues, S. 2007. Fermentation of cashew apple juice to produce high added value products. World J. Microbiol. Biotechnol., 23: 1409-1415.

Hornung, M., Ludwig, M., Gerrard, A.M. and Schmauder, H.P. 2006. Optimizing the production of bacterial cellulose in surface culture: Evaluation of substrate mass transfer influences on the bioreaction (Part 1). Eng. Life Sci., 6(6): 537- 545.
Hornung, M., Ludwig, M. and Schmauder, H.P. 2007. Optimizing the production of bacterial cellulose in surface culture: A novel aerosol bioreactor working on a fed batch principle (Part 3). Eng. Life Sci., 7: 35-41.

Hungund, B., Prabhu, S., Shetty, C., Srilekha, A., Veena, P. and Gupta, S.G. 2013. Production of bacterial cellulose from Gluconacetobacter persimmonis GH-2 using dual and cheaper carbon sources. J. Microbiol. Biochem. Technol., 5(2): 31-33.

Ishida, T., Mitarai, M. and Sugano, Y. 2003. Role of water soluble polysaccharides in bacterial cellulose production. J. Biotechnol. Bioeng., 83(4): 474-478.

Keshk, S.M. 2014. Bacterial Cellulose Production and its Industrial Applications. J. Bioprocess. Biotechniq., 4(2): 1-10.

Kurosumi, A., Sasaki, C. Yamashita, Y. and Nakamura, Y. 2009. Utilization of various fruit juices as carbon source for production of bacterial cellulose by Acetobacter xylinum NBRC 13693. Carbohydrate Polymers., 76(2): 333-335.

Lin, S.P., Liu, C.T., Hsu, K.D., Hung, Y.T., Shih, T.Y. and Cheng, K.C. 2016. Production of bacterial cellulose with various additives in a PCS rotating disk bioreactor and its material property analysis. Cellulose, 23(1): 367 - 377.

Pal, H., Joardar, M, Nikam, S. and Lele, S.S. 2019. Fermentative production of nata-de-mango and incorporation in beverage. J. Sci. Ind. Res., 78: 231-235.

Tigressa, H.S.R., Gustavo, A.S.P. and Luciana, R.B.G. 2008. Effects of inoculum concentration, temperature and carbon sources on tannase production during solid state fermentation of cashew apple bagasse. Biotechnol. and Bioprocess Engg., 13: 571-576.

Yessica, G.M and Ari, N.D. 2017. "Production of nata-deCoco using soaked soybean water as the alternative usage of Zwavelzuur Ammoniak (ZA)" in The $3^{\text {rd }}$ International Conference on Agro-Industry 2016 "Competitive \& Sustainable Agro-Industry: Value Creation in Agribusiness", KnE Life Sciences, pp. 43-50.

Zhou, L.L., Sun, D.P., Hu, L.Y., Li, Y.W. and Yang, J.Z. 2007. Effect of addition of sodium alginate on bacterial cellulose production by Acetobacter xylinum. Journal of Int. Microbiol. Biotechnol., 34: 483-489. 
